\title{
Wild Milk Thistle Unique Fatty Plant
}

\author{
Ibraheem M. Aliyas \\ Northern Technical University, Technical Institute of Mosul
}

\begin{abstract}
Milk thistle Silybum Marianum L. annual or biennial wild winter plant belongs to Asteraceae family widespread in north of Iraq particularly in Sulaimaniyah province. The botanical survey revealed that this plant became a third in coverage degree. Plant density reached $4.8 p l a n t / \mathrm{m}^{2}$, replication $40 \%$, found the higher plant in height was $110 \mathrm{~cm}$. This region is rich in floras vegetation cover which could be invested for anti-desertification, soil protection, sustainable biodiversity development and improvement of natural pastures. Its importance appearance as a medically by treating some diseases, milk thistle is better known as having medicinal benefits. It is a great tonic, increases appetite and aids in digestion. Including those who were addicted to alcohol to cleanse the liver. Used internally in the treatment of liver and gall bladder diseases, jaundice, cirrhosis, hepatitis and poisoning (including mushroom poisoning) through its containing several medicinal components as; linoleic acid64.59\%, oleic acid23.59\%, palmitic acid $12.62 \%$ and stearic acid 5.9\%. Treating components; silymarin 1.5-3\% tocopherol and 0.63\% sterols. Including Cholesterol, camp sterol, stigma sterol, sit sterol and some mucilage, the three principle components of silymarin are the flavanoligans silybin, silychristin, and silidianin. To plant nutritional importance due to its seeds components for the follows; protein 23\%, oils $26.65 \%$, ash $3.4 \%$, fiber4.55\% and carbohydrates $37.72 \%$. Also the plant contain some important elements such as magnesium, calicium; zinc and iron...etc.. Plant leaves as food eaten peaks cutworms and fresh as it palatable and useful of nutritional value. Contains mucilage substances, vitamins $(A, B 12, C, E, K)$ andsugars.
\end{abstract}

Keywords: Milk Thistle, Sulaymaniyah, Medical plant, Silybum Marianum.

\section{Introduction}

The research was conducted in Sulaymaneyah Governorate located in north east of Iraq, Latitude and Longitude $35^{\circ} 33^{\prime} 40^{\prime \prime}$ and $45^{\circ} 26^{\prime} 14^{\prime \prime}$ respectively. The region characterize by fertile soilclay texture and fit environmental conditions, where annual rainfall rate $656.05 \mathrm{~mm}$, rate of annualtemperature $19.6 \mathrm{c}^{0}$, annual rate of humidity $45 \%$ and amount rate of annual evaporation $162.7 \mathrm{~mm}[1]$.Silybum Marianum (milk thistle) is a genus of two species of thistle .The plants are native to the Mediterranean regions of Europe, North Africa, and the Middle East [2], ]. One species has been introduced elsewhere, including in North America. To plant several names such as; "Milk thistle" Marian thistle, Mary thistle, St. Mary's thistle, Our Lady's thistle, Holy thistle, Sow thistle, Blessed Virgin thistle, Christ's crown, Venue thistle, Heal thistle, Variegated Thistle, Wild Artichoke and scientific names as Carduus Marianus, Silybum marianum, derives from a feature of the leaves, which are prominently banded with splashes of white. Historically, these milky bands were said to be Mother Mary's milk, and this is the origin of another common name, St. Mary's thistle. The most widespread species is Silybum marianum. When processed into an ethanolic extract and sold as Milk Thistle Extract the composition; $65-80 \%$ Silymarin' concentrated from 1.5-3\% of the plant at $25-30 \%$ Fatty acids (Linoleic at $60 \%$, Oleic at 30\%, and Palmitic at 9\%) [3- 5]. Many of research show the active flavanoidlignan (flavanolignan) group of constituents, called silymarin, contained only in the seed shell has liver-protective and regenerative properties, as well as antioxidant effects. The liver-protective effects were known and written about in ancient times, leading to the active chemical, pharmacological. Clinical use for a variety of liver ailments, such as hepatitis, has also prospered throughout many parts of the world. Members of this genus grow as annual or biennial plants according to environmental factors. The erect stem is tall, branched and furrowed but not spiny. The large, alternate leaves are waxy-lobed, toothed and thorny, as in other genera of thistle. The lower leaves are cauline (attached to the stem without petiole). The upper leaves have a clasping base. They have large, disc-shaped pink-to-purple, rarely white, solitary flower heads at the end of the stem. The flowers consist of tubular florets. The phyllaries under the flowers occur in many rows, with the outer row with spine-tipped lobes and apical spines. The fruit is a black achene with a white pappus.Silybum eburneum Coss. \& Dur., known as the silver milk thistle, elephant thistle, or ivory thistle - Algeria, Morocco, Tunisia, Spain, Silybum eburneum Coss. \& Dur. Var. Hispanics Silybum marianum (L.) Gartner, the blessed milk thistle, which has a large number of other common names, such as variegated thistle [6-9]. Wide spread across much of Europe, Asia, and North Africa from Norway and the Canary Islands to China and Maluku; naturalized in Australia, New Zealand, and the Americas [6-10]. For over 2, 000 years, people around the world have enjoyed milk thistle in their diet. Just about all parts of the plant have been used as food with no reports of toxicity [11-15]. Although it can be used as food, milk thistle is better known as having medicinal benefits. It is a great tonic, increases appetite and aids in digestion. It is used by many people, including those who were addicted to alcohol to cleanse the liver. Milk thistle is used internally in the treatment of liver and gall bladder diseases, jaundice, cirrhosis, hepatitis and poisoning (including mushroom poisoning)[16-20]. Milk thistle is a stout, biennial or annual plant that grows up to one meter tall and has a branched, stem. This wild edible takes two years to complete the growing cycle. It is best known as having a unique shaped flower and leaves that are somewhat prickly to the touch if not careful. Each milk thistle flower can produce almost 200 seeds, with an average of 6,350 seeds per plant per year. Milk thistle flower heads average between 4 and 12 $\mathrm{cm}$. long, wide, and are light purple in colour. The leaves of the milk thistle are oblong to lanceolate in shape. They are either lobate or pinnate, with spiny edges. Leaves are hairless, are alternate, and have milky-white veins. The upper leaves clasp the stem. Milk thistle grows up to one meter tall.

\section{Volume 6 Issue 1, January 2017




\section{International Journal of Science and Research (IJSR) \\ ISSN (Online): 2319-7064}

Index Copernicus Value (2015): 78.96 | Impact Factor (2015): 6.391

Habitat of Milk thistle grows in dry, rocky soils, preferring sunny or lightly shaded areas. It also likes waste places in many areas around the world. The young stalks, leaves, roots and flowers can be eaten. Milk thistle root can be eaten raw or cooked. Leaves can be eaten raw or cooked however the very sharp leaf-spines must be removed first. When cooked these leaves make a great spinach substitute. Flower buds can be cooked [21-26]. The stems can be eaten raw or cooked for its sweat favorite. They are best when peeled and soaking is recommended to reduce the bitterness. Milk thistle can be used like asparagus or rhubarb or added to salads. They are at their best when used in spring when they are young. Roasted milk thistle seeds can be used as coffee Flower heads are reddishpurple with bracts ending in sharp spines. The small hard fruits in the flowers, known technically as achene, resemble seeds and are the part of the plant used medicinally [27-31].

\section{Materials and Methods}

This study was conducted in Sulaymaniyah region in spring of 2015/2016that made a survey for area in randomized method by wooden square in 50x50 dimensions. which the lands contain the spread of the plant So being counting the number of plant, coverage $\%$, replication, botanical description and vegetative growth characters in addition of studying a quality properties, chemical, nutritional composition and medicinal importance of plant .

\section{Discussion and Results}

Milk thistle Silybum Marianum L. annual or biennial winter plant belongs to Asteraceae family widespread in north of Iraq particularly in Sulaimaniyah province. The botanical survey revealed that this plant became a third in coverage degree. Plant density reached $4.5 \mathrm{plant} / \mathrm{m}^{2}$, replication was $40 \%$, found the higher height plant in flora region $112 \mathrm{~cm}$. Each milk thistle flower can produce 250 seeds, with an average of 6, 500 seeds per plant per year. Milk thistle flower heads average between 4 and $12 \mathrm{~cm}$. long and wide, and are light purple in colour. The leaves of the milk thistle are oblong in shape. They are either pinnate, with spiny edges. Leaves are hairless, are alternate, and have milkywhite veins. The upper leaves clasp the stem. Habitat of Milk thistle grows in dry, rocky soils, preferring sunny or lightly shaded areas. It also likes waste places in many areas around the world .The Marian, or Milk Thistle, is perhaps the most important medicinally among the members of this genus, however, assign it, naming it Silybum Marianum. Food uses of Milk Thistle; the Milk Thistle seeds have recently been used in preparation of biscuits, cake, and pizza. Up to $3 \%$ of the wheat flour replaced with test material. The resulting dough was more uniform, smoother and less sticky. The finished baked products have improved nutritional quality, crust color, texture, and symmetry and stayed fresh longer than control. Nutritional composition of Milk Thistle seeds, the seeds of plant have been evaluated for its oil, protein, fiber and mineral contents. The proximately composition of Milk Thistle seeds presented at table [4].Minerals and Nutrients; the role of trace elements in human nutrition and disease cannot be overemphasized. Even though the mineral elements form a small portion of total composition of most plant materials and of total body weight and they do not contribute to energy value of food, but they are of great physiological importance particularly in body metabolism .The results indicates that the seeds of test plant contains $\mathrm{Mg}$ 2, 225ppm, Ca 778.5ppm, Cu 108.3ppm, Fe 74.3ppm, Zn 69.4ppm, $\mathrm{Pb} 44.3 \mathrm{ppm}$, Ni 35.5, Mn 23.5ppm, $\mathrm{Cr} 6.8 \mathrm{ppm}$ and the $\mathrm{Cd} 3.2 \mathrm{ppm}$ showed the lowest concentration. It can be deduced that the seeds of Milk Thistle if consumed, could be a good source of minerals. Presences of rich amount of calcium and Magnesium are a special feature. Milk Thistle Protein, the defatted seeds contain an excellent quality and quantity of protein, ranging $23 \%$. The qualitative analysis of protein hydrolyzes revealed ten amino acids. Among these Aspartic acid, Glutamic acid, Glycine, and cystin were the major amino acids. Therefore the Milk Thistle meal as by product after its crush for oil could be used as a high protein animal and poultry feed. The unique composition of amino acids and important nutritional minerals make it rich feed. Milk Thistle oil, the seeds contain $26.65 \%$ fixed oil. The composition of the seed oil revealed that linoleic acid $64.59 \%$, oleic acid $23.59 \%$, palmitic acid $12.62 \%$ and stearic acid $5.9 \%$ are the predominant fatty acids. Milk thistle oil is fairly high in polyunsaturated fatty acids particularly an essential fatty acid i.e., linoleic acid (Omega-3), which is believed to be helpful in lowering cholesterol, when induced in the diet .Medicinal uses of milk thistle, the seeds, fruit and leaves of Milk Thistle have been used since the Roman times as a liver tonic, excellent food for cattle and horses. The standardized extract "Silymarin" is used in supportive therapy of liver disorder like stimulates protein synthesis in hepatic cells, improves disturbed hepatic functions. It contains mixture of flavonoids which contribute greatly to dietary sources of antioxidants and their intakes decreased the risk of coronary heart diseases and increases immunity to infectious cells and inhibit the growth of tumors. Consider the plant a good host for some insects as; aphids, ants, butterflies, ladybirds, mittens, this helps for natural balance between organisms to achieve the harmonies status in its native.

Table 1: Chemical composition of Milk thistle seeds

\begin{tabular}{|c|c|c|c|}
\hline Constituent & Amount $\%$ & Fatty acids types & Amount $\%$ \\
\hline Crude Moisture & 4.48 & Linoleic & 64.06 \\
\hline Protein & 23.0 & Oleic & 23.59 \\
\hline Oil & 26.23 & Palmitic & 12.62 \\
\hline Ash & 3.4 & Stearic & 5.9 \\
\hline Fiber & 4.55 & & \\
\hline Carbohydrates & 37.72 & & \\
\hline
\end{tabular}

\section{References}

[1] Ali Kh.M.alazzam, 2016, Evaluation vegetation cover in Sulaymaniyah region of Iraq, Int.j .Adv.Res.4 (9), pp., 2056-2060.

[2] Milk thistle."A Dictionary of Food and Nutrition. Retrieved December 22, 2016 from Encyclopedia.com: http://www.encyclopedia.com/education/dictionariesthesauruses-

[3] Montvale,, 1998, Medical Economics Corporation. The PDR for Herbal Medicines., NJ: Medical Economics Corporation book.

[4] Greenlee, H.K.; Yarnell, A.E.; Ladas, 2007, Clinical applications of Silybum marianumin on Ecology. Integer Cancer, (2)6, pp., 165-158

\section{Volume 6 Issue 1, January 2017




\section{International Journal of Science and Research (IJSR) ISSN (Online): 2319-7064 \\ Index Copernicus Value (2015): 78.96 | Impact Factor (2015): 6.391}

[5] Yahya Tawfiq al-Haj, 2003, Plant and Alternative Medicine, The house Arab Science, The PressMediterranean, University of Beirut-Lebanon.

[6] Fraschini, F.; Dermartini, G. and Esposti.D., 2002, Pharmacology of silymarin. Journal ofClin. Drug Invest, 22, pp., 51-65:

[7] Duke, J.A. 2004, Milk Thistle seed chemical, constituent. Journal of Sky herbals. 8, pp., 27-31.

[8] Greenle, H.; Abascal, K.; Yarnell, E. andLadas, E., 2007, Clinical application of Silybummarianum in oncology. IntegerCancer, 6(2):, 104-109.

[9] Narayana, K.R.; Reddy, M.S.; ChaluvadiM.R and Krishna, D.R., 2001, classification, pharmacological BioflavonoidBiochemical effects and therapeutic potentIndian .J.pharmol.33:, pp., 1-2. https://en.wikipedia.org/wiki/Silybum_marianum.

[10] Cheung CW, Gibbons N, Johnson DW, Nicol DL., 2010, Silibinin-a promising new treatment for cancer. Anticancer Agents Med Chem; 10:186-95.

[11] Kroll DJ, Shaw HS, Oberlies NH., 2007, Milk thistle nomenclature: why it matters in cancer research and pharmacokinetic studies. Integrative cancer therapies; 6(2):110-119.

[12]Loguercio C, Festi D., 2011, Silybin and the liver: from basic research to clinical practice. World J gastroenterology; 17:2288-301

[13] Brantley SJ, Oberlies NH, Kroll DJ, Paine MF., 2010, Two flavonolignans from milk thistle (Silybum marianum) inhibit CYP2C9-mediated warfarin metabolism at clinically achievable concentrations. J PharmacolExpTher.; 332:1081-87.

[14]Flaig TW, Glode M, Gustafson D, van BA, Tao Y, Wilson S et al., 2010, A study of high-dose oral silybin-phytosome followed by prostatectomy in patients with localized prostate cancer, Prostate.; 70:848-55.

[15]Hoh C, Boocock D, Marczylo T, Singh R, Berry DP, 2006, Dennison Pilot study of oral silibinin, a putative chemo preventive agent, in colorectal cancer patients: silibinin levels in plasma, colorectal, and liver and their pharmacodynamics consequences. Clin Cancer Res.; 12:2944-50.

[16] Greenlee H, Abascal K, Yarnell E, Ladas E., 2007, Clinical applications of Silybum marianum in oncology. Integrative cancer therapies; 6(2):158-165.

[17] Post-White J, Ladas EJ, Kelly KM., 2007, Advances in the use of milk thistle (Silybum marianum). Integrative cancer therapies; 6(2):104-109.

[18] Saller R, Melzer J, Reichling J, Brignoli R, Meier R., 2007, An updated systematic review of the pharmacology of silymarin. Forschende Komplementärmedizin/Research in Complementary Medicine; 14(2):70-80.

[19] McBride A, Augustin KM, Nobbe J, Westervelt P., 2012, Silybum marianum (milk thistle) in the management and prevention of hepatotoxicity in a patient undergoing reinduction therapy for acute myelogenous leukemia. Journal of Oncology Pharmacy Practice; 18(3):360-365.

[20] Deep G, Agarwal R., 2007, Chemo preventive efficacy of silymarin in skin and prostate cancer. Integr Cancer; $6: 130-145$.
[21] Colombo V, Lupi M, Falcetta F, Forestieri D, D’Incalci M, Ubezio P., 2011, chemotherapeutic activity of silymarin combined with doxorubicin or paclitaxel in sensitive and multidrug-resistant colon cancer cells. Cancer Chemo-Pharmacology; 67(2):369-379.

[22] Scambia G, De Vincenzo R, Ranelletti P, Benedetti Panici P, Ferrandina G, D'Agostino G, et al, 1996, Antiproliferative effect of silybin on gynecological malignancies: Synergism with cisplatin and doxorubicin. Eur J Cancer; 32(5):877-882.

[23] Rambaldi A, Jacobs BP, Iaquinto G, Gluud, 2005C, Milk thistle for alcoholic and/or hepatitis( B or C) liver diseases--a systematic Cochraneheap to-biliary group review with meta-analyses of randomized clinical trials. Am J Gastroenterology; 100:2583-91.

[24] Tamayo C, Diamond S., 2007, Review of Clinical Trials Evaluating Safety and Efficacy of Milk Thistle (Silybum marianum [L.] Integrative Cancer Therapies, 01; 6(2):146-157.

[25] Vidlar A, Vostalova J, Ulrichova J, Student V, Krajicek M, Vrbkova J, et al, 2010, The safety and efficacy of a silymarin and selenium combination in men after radical prostatectomy-a six month placebo-controlled doubleblind clinical trial. Biomedical Papers; 154(3):239-244.

[26] Becker-Scheibe, M., Mengs, M., Schaefer, M., Bulitta, M/ and Hoffman, W., 2011, Topical use of a silymarinbased preparation to prevent radiodermatitis: results of a prospective study in breast cancer patients, 187(8):485491.

[27] Van Erp NPH, Baker SD, Zhao M, Rudek MA, Guchelaar HJ, Nortier JWR, et al, 2005, Effect of milk thistle (Silybum marianum) on the pharmacokinetics of irinotecan. Clinical cancer research; 11(21):7800-7806.

[28] Han Y, Guo D, Chen Y, Chen Y, Tan ZR, Zhou HH, 2009, Effect of silymarin on the pharmacokinetics of losartan and its active metabolite E-3174 in healthy Chinese volunteers. Eur J Clin Pharmacology.; 65:58591.

[29] Flaig TW, Gustafson DL, Su LJ, Zirrolli JA, Crighton F, Harrison GS et al, 2007, pharmacokinetic study of silybin-phytosome in prostate cancer patients. Invest New Drugs; 25:139-46.

[30] National Center for Complementary and Alternative Medicine (2012). Get the facts. Hepatitis C: A focus on dietary supplements. (NCCAM Publication, No. D422)http://nccam.nih.gov/health/hepatitisc/hepatitiscfac ts.htm?nav $=\mathrm{gsa} 2$

[31] Murray MT., 2013, Silybum marianum-milk thistle, Textbook of Natural Medicine, 4th ed., pp. 1026-1031. St. Louis: Mosby. 